\title{
University Professors' Level Of Technological Skills And Its Relationship To The Orientation Towards E-Learning
}

\author{
Asmaa Ouda Sachit, Asst.Prof.Dr.Mohammed Mahdi Sikhee \\ University of Misan, College of Basic Education \\ asmaaasma935@gmail.com \\ University of Misan, College of Education \\ Mohammad_mehdi@uomisan.edu.iq
}

\begin{abstract}
The aim of this research is to determine the level of university professors' technological skills and its relationship to the orientation towards electronic education. To achieve the objectives of this research, five null hypotheses were formulated. We used the descriptive method and chose a random sample of university professors totalling around (200) professors distributed among (14) colleges of Dhi Qar University. In order to achieve the research objectives, we prepared two tools: the first is a technological skills questionnaire consisting of (45) constructs which included six main skills (preparation and planning skill, implementation skill, mastery of scientific material, skill of using pedagogical techniques, evaluation skill, classroom management skill). The validity and robustness of the questionnaire were verified.

The second tool is a scale to measure the orientation towards e-learning that included five areas (university professors' vision of elearning, motivation in e-learning, the desired benefit of e-learning in society, fun in e-learning, self-concept in e-learning). The scale consisted of of (54) constructs the validity and robustness of which were also verified. The research tools were applied to the research sample of (200) professors and the research results were statistically treated using the Statistical Package for Social Sciences (SPSS) program.

The results showed that the sampled professors have a higher-than-average level of technological skills as well as statistically significant positive orientation towards electronic education. Results also showed that there is a positive relationship between the level of university professors' mastery of technological skills and their orientation towards electronic learning. In light of the research results, we presented a number recommendations and proposals.
\end{abstract}

Keywords:

(University Professors, Technological Skills, Orientation, E-Learning)

Article Received: 18 October 2020, Revised: 3 November 2020, Accepted: 24 December 2020

\section{Research problem}

Despite the multiplicity of the university's roles, the real outlet for these is the university professor. Therefore, it is the responsibility of university professors to implement them at the level of scientific research that provides society with knowledge that qualifies its members to keep pace with what is going on around them. It is also their responsibility to enhance the knowledge of individuals in the process of functional qualification within the educational process or community service with both tasks. In addition, they adopt methods that achieve these goals and spread the culture of relying on innovation in addressing emerging or urgent issues. Therefore, professors occupy an important position in universities because of their role in preparing a generation capable of dealing with and benefiting from technological developments as well as being mentally and professionally prepared to keep pace with these developments. In fact, adopting any positive or negative direction on any issue or event is a true indicator of the level of capabilities, skills and technical expertise that they possess and enable them to deal with various devices and means.

This study seeks to answer a number of questions based on what has been presented above and in line with the step of adopting electronic education in Iraqi universities as an alternative to traditional education. This alternative approach requires a level of technological skills that qualify the faculty members to i) carry out their tasks at the required level in an active educational environment centered on students and ii) make teaching more successful in achieving educational 
goals by employing these skills. This in turn requires a logical organization in which multiple sources of knowledge are available for students in their different characteristics, capabilities and needs. In light of this, the current study problem can be highlighted by answering the following questions:

- What is the level of technological skills of university professors?

- What kind of orientation that university professors have towards e-learning?

- What is the type of correlation between the level of university professors' skill mastery and their orientation towards e-learning?

\section{The significance of the study}

The scientific progress of any nation depends on its ability to keep pace with the times by being familiar with all available and organized knowledge and conducting studies and research. The more knowledge is intense and easy to deal with, the more it leads to the advancement and prosperity of society. Knowledge is the final outcome of scientific research and creativity and this requires maximally benefitting from the available knowledge and adapting to it to produce local knowledge. This is achieved through securing learning for everyone in addition to harnessing all innovations in a manner commensurate with the information revolution and the huge knowledge and technical explosion that the current era is witnessing (Al-Hariri, 2016, p. 184). This means that educational institutions must help learners, particularly students, to keep up with scientific and technological progress. This represents a pillar for improving the quality of life in society and a means for the desired scientific advancement (Ali, 2009, p. 25).

The educational systems that bear the responsibility of preparing young people need constant review in order to improve their internal competence. This is operationalised by choosing the best inputs that are consistent with the educational reality so that the outputs of the systems meet the level of ambition of their societies. Competency-based movement is relatively valid for all levels and school subjects. It is an active movement that makes teachers more positive and effective in influencing their students (Khazali \& Momani, 2010, p. 555).

Al-Far (2004) referred to the future prospects and the shape of the educational institution whereby the role of the university professor will diminish in the undergraduate-level and higher-studies institutions. It will be limited to consulting at the university or individual level and students will end up in front of computer screens using the Internet to obtain information from different universities (Al-Far, 2004, p. 84).

Due to the nature of these modern technologies in education, educational institutions have found themselves in great challenges to strike balance between these technical applications in education and achieving educational goals through them. Therefore, intellectuals, specialists and technical experts have taken upon themselves to help these institutions in developing policies, standards and organizational rules to i) place distance education programs on the right direction to becoming part of the accredited education and ii) provide them with continuous feedback programs for the structure of these systems.

One of the aspects of change and renovation that occurred in teacher education systems has been the shift from traditional systems to relying on the concept of competence where a strong movement emerged calling for teacher preparation and training on the basis of competencies. This movement has succeeded remarkably because it is consistent with the concept of continuous education and modern-day realities (Al-Lulu, 2001, p. 53).

The university professor must be able to master a set of skills such as the use of equipment and the production of educational tools and programs. This requires preparing him/her not only academically but also in terms of professional competencies especially those related to 
educational technology in order to be reflected in their teaching performance to achieve the desired goals (Salem, 2004, p. 258).

Employing technological skills in the educational process by faculty members helps in activating education, increasing the level of production, improving outputs and making it more flexible which would help in reaching the best results (AlHusban, 2014).

As a result of the tremendous technical development, great changes occurred in education as new patterns and methods appeared in education. One of these methods is electronic education whereby the ease of use of the Internet and many other technical means led to the removal of classroom barriers to include the electronic space thereby opening new horizons for learning and training and communication. The success of e-learning requires fruitful cooperation and remarkable efforts in properly planning and developing academic curricula. Thus, there must be educational and technical competencies and previous knowledge that the teacher must possess in order to interact with educational sites and their tools and to communicate with his/her students using synchronous or asynchronous education and interact with the content provided through these sites (Hamza, 2015, p. 112).

Many studies have indicated that university professors' possession of an acceptable level of technological skills helps in achieving many educational goals especially those that have shown differences in their possession according to several variables. These include gender, experience, academic specialization and the orientation towards technology and its methods applied in the educational field as in (Al-Ajrami, 2012), (Hassan, 2012) and (Quneibi, 2016).

And based on the aforementioned, the significance of of this study can be stated as follows:

1- The importance of the current research stems from the importance of studying the field in which it was applied, namely higher education institutions as a pioneering sector.
2- The scarcity of local research and studies (according to the best of our knowledge) that dealt with technological skills at the local and Arab levels. The selection and qualification of university professors have still not been fulfilled yet. There is a necessity to keep pace with scientific progress and employ technological innovations in university education and online education.

3- Determining the level of mastery of technological skills of university professors and the extent to which they use them help to consolidate these skills in a direct and fundamental way. The subject of technological skills is of paramount importance in the transition from the level of quantitative learning to the qualitative level.

4- The importance of this study stems from studying the professors' mastery of technological skills as it is an attempt to confirm the importance of technological skills. This contributes to the development of teaching strategies used in elearning in universities.

5- This study provides a scale to measure the orientation towards e-learning and a measure of technological skills that benefit researchers in other research topics.

6- This study can also help university faculty members in identifying the most important technological teaching skills to increase their experience, improve their performance and develop their job performance. The faculty members 'possession as well as use of e-learning skills can in turn contribute to the development of the learner's technical skills.

7- Presenting a vision for those concerned with developing e-learning in universities for future planning to integrate and adopt technology in higher education programs towards improving education outcomes.

8- The possibility of the research results to contribute towards determining the skills needed to apply e-learning at the university level.

9- The current research provides an opportunity for researchers to conduct similar research. 


\section{Research Aims}

The current research aims to:

1- Measure the level of technological skills of university professors.

2- Determine the university professors 'orientation towards e-learning

3- Discover the correlation between university professors 'level of technological skills and their orientation towards e-learning.

\subsection{Research Hypotheses}

To achieve the objectives of the research, the following hypotheses were formulated:

1- There is no statistically significant difference at the level of significance of (0.05) between the average scores of the research sample on the scale of technological skills and the hypothetical average.

2- There is no statistically significant difference at the level of significance of (0.05) between the average scores of university professors on the orientation towards e-learning scale and the hypothetical average.

3 - There is no statistically significant difference at the level of significance of (0.05) between technological skills of university professors according to the variable of gender, experience, scientific title and academic specialization (Science, Humanities).

4- There is no statistically significant difference at the level of significance of (0.05) between the orientation towards electronic education among university professors according to the variable of gender, experience, scientific title and academic specialization (science, humanities).

5- There is no statistically significant correlation relationship at the level of significance of (0.05) between the University of Technology professors' skills and the orientation towards e-learning.

\subsection{Research Limitations}

1-;Spatial: Dhi Qar University / Iraq

2- Time: (2019-2020 AD)
2- Human: University professors at Dhi Qar University

4- Objective: these are technological skills and the orientation towards e-learning.

\section{Defining Terminologies}

1- Technological skills: It is a group of competencies prepared by the International Society for Educational Technology. It is a set of basic ideas, knowledge and skills related to the themes of information technology (creativity and innovation, communication and cooperation, research and information flow, critical thinking and problem solving, decision-making, digital citizenship, concepts and processes of technology (Othman and Al-Jundi, 2015, p. 3).

The researchers define technological skills procedurally: a set of ideas, knowledge, capabilities and basic skills that a university professor must possess in the field of applying elearning. It can also be defined as his/her ability to employ technology and learning systems in the educational virtual classroom in planning, preparing, managing, implementing and evaluating the lessons and electronic lectures.

2- The orientation: Al-Makhzoumi (1989) defines it "the outcome of an individual's perception and feeling towards a specific topic, which drives him/her to behave positively or negatively" (AlMakhzoumi, 1989, p. 64).

Wahid (2001) gives the following definition "It is an organized and coordinated method of thinking, feeling and reaction towards people, groups, social issues, or any event in the environment" (Wahid, 2001, p. 41).

We define the orientation as a procedure and state that it is a set of judgments that a university professor possesses. These judgments were formed as a result of his/her acquired experiences at work and can be related to the level of rejection, acceptance or neutrality. Through this, the university professor expresses his/her position on electronic education and is measured by the degree that he/she obtains as a result of his/her 
response to the parameters of the scale prepared for this purpose.

3- E-learning: this is defined by Salem (2004) as "an educational system that provides educational or training programs to learners or trainees at any time and place using interactive information and communication technologies in order to provide a synchronous and asynchronous multi-source learning environment based on self-education and interaction between teacher and learner" (Salem, 2004, p. 289).

\section{Research Methodology and Procedures}

\subsection{The methodology of the study}

We adopted the descriptive approach to study the relationships as the appropriate approach for this type of studies. Correlational studies describe the degree to which the study variables are related. Relational research includes collecting information in order to determine to what degree there is a relationship between two or more variables and expresses. Relationship is expressed by the value of correlation coefficient (AlDhamin, 2007, p. 135).

\subsection{The Research Community:}

This means all individuals, things, or people who are the subject of the research problem, and it is all the individuals related to the study problem that the researcher seeks to generalize the results of the study on them (Abu Al-Nasr, 2004, pp. 131-132).

In this study, the research community consisted of (1168) professors who are currently affiliated with at Dhi Qar University and from (9) colleges of science disciplines while (5) represented colleges of humanities for the academic year (2019-2020).

\subsection{The Research Sample}

The research sample "is a partial group of the research community, and is the best representative of the elements of the original community. It also preserves all the characteristics of the original community in order to be representative of that community so that the results of that sample can be generalized to the entire community (Abu AlNasr, 2004, p. 133).

The researcher randomly selected her research sample, which was (200) university professors forming $20 \%$ of the research community.

\subsection{The Research Tools}

A questionnaire was adopted as a tool for this study as it fits appropriately with the nature and purpose of the research. The questionnaire is the best way to achieve the objectives of the research. Two tools were prepared for this study:

1- Technological skills: since it was necessary to prepare a scale that measures technological skills, the researchers reviewed the literature that clarified the concept of technological skills. Then, a technological skills scale was prepared and this consisted of (45) constructs representing the technological skills of the faculty members. The validity of the procedure was verified by a group of arbitrators with experience and competence until they appeared in final form (See Appendix 4) consisting of two parts. The first is general data related to individuals in terms of specialization, gender, scientific title and years of experience, and the second part consists of (45) parameters distributed into six areas: the skill of preparation and planning; the skill of implementation; the skill of mastering the scientific material; the skill of using educational techniques; the evaluation skill; the skill of classroom management.

2- The orientation towards e-learning: in order to prepare a scale that measures the orientation of university professors towards e-learning, the researchers examined the literature that clarified the concept of orientation as well as methods of measurement. Then the researchers prepared a measure of the orientation towards e-learning consisting of (54) constructs divided between five areas (the professor's vision of University elearning; the drive for e-learning; the desired benefit of e-learning in society; the fun in elearning and the concept of self in e-learning. 
These represent the orientation of university professors towards e-learning. The validity and reliability if these were found after it was presented to a group of arbitrators until it appeared in the final form.

\subsection{Validity:}

The researchers relied on two types of validity.

1- The apparent validity, which is intended to verify the validity of the tool used to measure the availability of technological skills and the validity of its statement in terms of its formulation and comprehensiveness for the objectives of the research. This is done by presenting it to a group of experts and arbitrators and adopting an agreement percentage of $(80 \%)$ as a criterion for accepting the validity of the tool. This was achieved as the tool got apparent validity.

2- Validity of internal consistency or structural Validity:

This is the calculation of the correlation coefficient between each parameter. It is the dimension to which those constructs belong on the one hand and the correlation between each dimension separately and the scale as a whole on the other. This means that this method measures the extent of the coherence of the expressions as a whole or each dimension on the scale so that the overall degree of the scale is a test of validity with each of the dimensions.

\subsection{Reliability}

Reliability is considered one of the psychometric properties that are indispensable to the researcher in terms of the use of its measures. The more reliable the scale, the more we rely on it in making decisions as it has validity and reliability
(Kerlinger, 1979, p. 442). The reliability was obtained by applying it to an exploratory sample, other than study sample, consisted of (40) individuals. The reliability coefficient was obtained using the (Alpha Cronbach) equation and the reliability coefficient for the tool was (0.70). This is considered a good coefficient that can be relied upon for the purposes of the study.

\subsection{Application of the two research tools:}

The research tools discussed above were applied to the basic research sample constructed for the study, which consisted of (200) professors from Dhi Qar University.

\section{Presentation and discussion of results:}

1- The first step was to verify the validity of the first hypothesis, which states that there is no statistically significant difference at the level of significance $(0.05)$ between the average scores of the research sample on the technological skills scale and the hypothesis average. To achieve this and in order to determine the level of technological skills of the research sample, the researchers calculated the arithmetic mean of the sample in the skill scale. This reached a value of (175.705) and a standard deviation of (24.565). After using the $t$-test for one sample, the calculated T-value was (24.009). When compared to the tabular value of (1.98) at a level of significance (0.05) and a degree of freedom (199), it was found that it is greater than it. This indicates the existence of a significant difference. Therefore, we reject the null hypothesis and accept the alternative meaning that the research sample possesses a higher level than the median of technological skills.

Table (1): The arithmetic mean, standard deviation, and the calculated and tabular T-value of the research sample scores on the technological skills scale.

\begin{tabular}{|c|c|c|c|c|c|c|c|}
\hline Sample & $\begin{array}{c}\text { Numbe } \\
\mathrm{r}\end{array}$ & $\begin{array}{c}\text { Arith } \\
\text { metic } \\
\text { mean }\end{array}$ & $\begin{array}{c}\text { Standar } \\
\mathrm{d} \\
\text { deviati }\end{array}$ & $\begin{array}{c}\text { Media } \\
\mathrm{n}\end{array}$ & $\begin{array}{c}\text { Degree of } \\
\text { freedom }\end{array}$ & t-value & $\begin{array}{c}\text { Significance } \\
(0.05)\end{array}$ \\
\hline
\end{tabular}




\begin{tabular}{|c|c|c|c|c|c|c|c|c|}
\hline & & & on & & & tabular & calculated & \\
\hline $\begin{array}{c}\text { Univers } \\
\text { ity } \\
\text { profess } \\
\text { ors }\end{array}$ & 200 & $\begin{array}{c}176.70 \\
5\end{array}$ & 24.565 & 135 & 199 & 1.98 & 24.009 & $\begin{array}{c}\text { Statistically } \\
\text { significant }\end{array}$ \\
\hline
\end{tabular}

2- The validity of the second hypothesis was verified. This hypothesis states that there is no statistically significant difference at the level of significance $(0.05)$ between the average scores of the university professors on the scale of the orientation towards e-learning and the hypothetical average. To achieve this and in order to assess the university professors' tendency towards e-learning, the researchers calculated the arithmetic mean of the sample's scores on the orientation scale. This stood at (188.080) and a standard deviation of (20.885). After conducting the $t$-test for one sample, the calculated T-value was (17.695) and when compared to the tabular value of (1.98) at a level of significance (0.05) and a degree of freedom of (199), it appeared that it is greater than it. This indicates the existence of a significant difference. Accordingly, we reject the null hypothesis and accept the alternative and this means that the research sample has a positive orientation towards e-learning.

Table (2): The arithmetic mean, standard deviation, and the calculated and tabular T-value of the scores of the research sample on the orientation scale towards e-learning.

\begin{tabular}{|c|c|c|c|c|c|c|c|c|}
\hline \multirow{2}{*}{$\begin{array}{l}\text { Sampl } \\
\text { e }\end{array}$} & \multirow{2}{*}{$\begin{array}{c}\text { Numbe } \\
\mathrm{r}\end{array}$} & \multirow{2}{*}{$\begin{array}{l}\text { Arithmeti } \\
\text { c mean }\end{array}$} & \multirow{2}{*}{$\begin{array}{c}\text { Standard } \\
\text { deviatio } \\
n\end{array}$} & \multirow{2}{*}{$\begin{array}{l}\text { Media } \\
\mathrm{n}\end{array}$} & \multirow{2}{*}{$\begin{array}{l}\text { Degree } \\
\text { of } \\
\text { freedo } \\
\mathrm{m}\end{array}$} & \multicolumn{2}{|c|}{ t-value } & \multirow{2}{*}{$\begin{array}{c}\text { Significance } \\
(0.05)\end{array}$} \\
\hline & & & & & & tabular & $\begin{array}{c}\text { calculate } \\
\text { d }\end{array}$ & \\
\hline $\begin{array}{l}\text { Univer } \\
\text { sity } \\
\text { profes } \\
\text { sors }\end{array}$ & 200 & 188.080 & 20.889 & 162 & 199 & 1.98 & 17.659 & $\begin{array}{l}\text { Statistically } \\
\text { significant }\end{array}$ \\
\hline
\end{tabular}

The researchers attribute the emergence of a positive orientation among university professors towards e-learning to the quality of a university professor to innovate and search for the best methods that would achieve educational goals.

3- The validity of the third hypothesis was verified. This hypothesis states that there are no statistically significant differences at the level of significance $(0.05)$ between the average scores of the university professors on the technological skills scale according to the specialism variable. To achieve this and in order to also verify the validity of the third hypothesis, which states (there is no statistically significant difference at the level of significance (0.05) between the technological skills of university professors according to the variable of gender, experience, scientific title and academic specialism (Science, Humanities), the researchers calculated the arithmetic mean and the standard deviation of individual scores of the sample on the scale of technological skills according to the variables (academic specialism, gender, experience and scientific title) respectively and as indicated in Tables (3), (4), (5) and (6). This was obtained by conducting a $t$-test 
for two independent samples as it was found that the calculated $\mathrm{T}$ value is (4.505), which is greater than the tabular value of (1.98). This means that there are statistically significant differences for technological skills and in favour of scientific specialization.

Table (3)

The results of the $t$-test indicating the differences between the average scores of university professors in the scale of technological skills according to academic specialization (Science \& Humanities).

\begin{tabular}{|c|c|c|c|c|c|c|}
\hline $\begin{array}{c}\text { Technological } \\
\text { skills }\end{array}$ & $\begin{array}{c}\text { Arithmeti } \\
\text { c mean }\end{array}$ & $\begin{array}{c}\text { Standard } \\
\text { deviation }\end{array}$ & $\begin{array}{c}\text { Degree } \\
\text { of } \\
\text { freedom }\end{array}$ & \multicolumn{2}{|c|}{ t-value } & $\begin{array}{c}\text { Significance } \\
(0.05)\end{array}$ \\
\cline { 5 - 6 } & & & & 1.98 & 4,505 & $\begin{array}{c}\text { Statistically } \\
\text { scignificant }\end{array}$ \\
\hline Humanities & 176.550 & 22.748 & & & & \\
\hline
\end{tabular}

The researchers ascribe the reason for this to the fact that university professors with scientific discipline have foreign interests and views caused by the nature of scientific disciplines, since most of them are taught in English. This made it easier for them to deal with many obstacles that encounter surfers of educational websites, especially those written in the English language.

Table (4)

The results of the $t$-test indicating the differences between the average scores of university professors in the scale of technological skills according to the variable of gender.

\begin{tabular}{|c|c|c|c|c|c|}
\hline \multirow[t]{2}{*}{ Technological skills } & \multirow{2}{*}{$\begin{array}{c}\text { Arithmetic } \\
\text { mean }\end{array}$} & \multirow{2}{*}{$\begin{array}{l}\text { Standard } \\
\text { deviation }\end{array}$} & \multicolumn{2}{|c|}{ t-value } & \multirow{2}{*}{$\begin{array}{c}\text { Significance } \\
(0.05)\end{array}$} \\
\hline & & & tabular & calculated & \\
\hline Male & 178.390 & 20.710 & \multirow[t]{2}{*}{1,98} & \multirow[t]{2}{*}{3.870} & \multirow{2}{*}{$\begin{array}{r}\text { Statistically } \\
\text { significant }\end{array}$} \\
\hline Female & 162.860 & 34.373 & & & \\
\hline
\end{tabular}

The researchers believe that despite the rapprochement of the university environment between males and females, the results were in favour of males. This result may be due to the males' possession of more technological skills than females and this can be primarily ascribed to the social environment. To confirm the significant differences between the four totals in technological skills depending on the levels of scientific title (Professor, Assistant Professor, instructor, Assistant instructor) of the sample.
The total of the variance between the four groups and the value of variance within each group was calculated by using the one-way analysis of variance (ANOVA). To check if the direction of the differences is in favor of any of the four groups according to the statistical significance, the method of least significant difference (LSD) was used. It was found that the significant differences in favor of the first group that represent the level of the scientific title (professor) is due to the fact that there is an effect of the scientific title variable 
and that the professor's experience in university teaching has a role in qualitatively developing these skills.

Table (5)

Analysis of the variance of the four groups in accordance with the levels of scientific title (Professor, Assistant Professor, instructor, Assistant instructor) in the technological skills of the reseach sample.

\begin{tabular}{|c|c|c|c|c|c|c|}
\hline \multirow[t]{2}{*}{$\begin{array}{ll}\text { Source of } \\
\text { difference }\end{array}$} & \multirow[t]{2}{*}{$\begin{array}{l}\text { Degree of } \\
\text { freedom }\end{array}$} & \multirow[t]{2}{*}{$\begin{array}{l}\text { Total of } \\
\text { squares }\end{array}$} & \multirow[t]{2}{*}{$\begin{array}{l}\text { Mean of } \\
\text { squares }\end{array}$} & \multicolumn{2}{|l|}{ f-value } & \multirow[t]{2}{*}{$\begin{array}{l}\text { Significance } \\
(0.05)\end{array}$} \\
\hline & & & & tabular & calculated & \\
\hline Inter-group & 3 & $\begin{array}{l}35636.9 \\
96\end{array}$ & $\begin{array}{l}11878.9 \\
99\end{array}$ & \multirow[t]{3}{*}{3.949} & \multirow[t]{3}{*}{10.079} & \multirow{3}{*}{$\begin{array}{l}\text { Inter-group } \\
\text { Statistically } \\
\text { significant } \\
\text { differences }\end{array}$} \\
\hline Intra-group & 196 & $\begin{array}{l}230586 . \\
124\end{array}$ & $\begin{array}{l}1176.46 \\
0\end{array}$ & & & \\
\hline Total & 162.860 & $\begin{array}{l}266223 . \\
120\end{array}$ & & & & \\
\hline
\end{tabular}

It was found that there are significant differences between the four groups in technological skills according to the level of experience variable (5 years, 10 years, 15 years, 20 years) for the research sample. To ascertain if the direction of the differences is in favor of any of the four groups according to the statistical significance after using the one-way analysis of variance

Table (6)
(ANOVA), least significant difference (LSD) method was used showing that the significant differences are in favor of the fourth group, which represents the level of years of experience (20 years).

Analysis of variance of the four groups according to the levels of experience variable (5 years, 10 years, 15 years, 20 years) in technological skills of the research sample.

\begin{tabular}{|c|c|c|c|c|c|c|}
\hline \multirow{2}{*}{$\begin{array}{l}\text { Source of } \\
\text { difference }\end{array}$} & \multirow{2}{*}{$\begin{array}{l}\text { Degree of } \\
\text { freedom }\end{array}$} & \multirow{2}{*}{$\begin{array}{l}\text { Total of } \\
\text { squares }\end{array}$} & \multirow[t]{2}{*}{$\begin{array}{l}\text { Mean of } \\
\text { squares }\end{array}$} & \multicolumn{2}{|c|}{ f-value } & \multirow{2}{*}{$\begin{array}{c}\text { Significanc } \\
\text { e }(0.05)\end{array}$} \\
\hline & & & & tabular & $\begin{array}{c}\text { calcul } \\
\text { ated }\end{array}$ & \\
\hline Inter-group & 3 & $\begin{array}{c}23752.4 \\
88\end{array}$ & $\begin{array}{c}7917.49 \\
6\end{array}$ & \multirow[t]{3}{*}{3.949} & \multirow[t]{3}{*}{6.967} & \multirow{3}{*}{$\begin{array}{l}\text { Inter-group } \\
\text { Statistically } \\
\text { significant } \\
\text { differences }\end{array}$} \\
\hline Intra-group & 196 & $\begin{array}{c}2222731 \\
.10\end{array}$ & $\begin{array}{c}1136.38 \\
3\end{array}$ & & & \\
\hline Total & 162.860 & 246483. & & & & \\
\hline
\end{tabular}


The statistical differences were found in favour of the fourth group, which represents the level of years of experience (20 years). The researchers attribute the reason for this to the fact that the experience in university teaching has been acquired by the professors throughout the years they spend in the university milieu.

4- In this step, we verified the validity of the fourth hypothesis, which states that there is no statistically significant difference at the level of significance (0.05) between the orientation towards electronic education among university professors according to the variable of academic specialization (scientific, humanitarian), gender, scientific title and experience. To do this, the arithmetic mean and standard deviation of the research sample scores were calculated on the orientation towards electronic education scale. This stood at $(195,610$.) with a standard deviation of $(15,016)$ for the humanities and an arithmetic mean (.180,550) and a standard deviation $(23,169$.) for the science disciplines. After using the $t$-test for two independent samples equal in number, the calculated T-value was $(5,455)$ and smaller than the tabular value at the level of significance (0.05). This means that it is not statistically significant and as shown in tables (7), (8), (9) and (10).

Table (7)

The results of the $t$-test for two samples, the orientation of university professors towards electronic education according to the variable of specialization (science, humanities).

\begin{tabular}{|c|c|c|c|c|c|c|c|}
\hline \multirow[t]{2}{*}{ Sample } & \multirow{2}{*}{$\begin{array}{l}\text { Arithmeti } \\
\text { c mean }\end{array}$} & \multirow{2}{*}{$\begin{array}{l}\text { Standard } \\
\text { deviation }\end{array}$} & \multirow{2}{*}{$\begin{array}{c}\text { Media } \\
\mathrm{n}\end{array}$} & \multirow{2}{*}{$\begin{array}{l}\text { Degree } \\
\text { of } \\
\text { freedom }\end{array}$} & \multicolumn{2}{|c|}{ t-value } & \multirow{2}{*}{$\begin{array}{c}\text { Significance } \\
(0.05)\end{array}$} \\
\hline & & & & & tabular & calculated & \\
\hline Science & 195.610 & 15.016 & 162 & 198 & 1.98 & 5.455 & $\begin{array}{l}\text { Statistically } \\
\text { significant }\end{array}$ \\
\hline Humanities & 180.550 & 23.169 & & & & & \\
\hline
\end{tabular}

The researchers explain that the absence of differences does not mean a decrease or hesitation towards e-learning. The responses of the faculty members appeared homogeneous, and there were no statistically significant differences.

(Table 8): The results of the t-test to indicate the differences between the mean scores of university professors in the trend scale according to the variable of gender (male, female).

\begin{tabular}{|c|c|c|c|c|c|c|}
\hline \multirow{2}{*}{$\begin{array}{l}\text { Technologica } \\
1 \text { skills }\end{array}$} & \multirow{2}{*}{$\begin{array}{l}\text { Arithmetic } \\
\text { mean }\end{array}$} & \multirow{2}{*}{$\begin{array}{l}\text { Standar } \\
\mathrm{d} \\
\text { deviatio } \\
\mathrm{n}\end{array}$} & \multirow{2}{*}{$\begin{array}{l}\text { Degree } \\
\text { of } \\
\text { freedo } \\
\mathrm{m}\end{array}$} & \multicolumn{2}{|c|}{ t-value } & \multirow{2}{*}{$\begin{array}{l}\text { Significance } \\
(0.05)\end{array}$} \\
\hline & & & & $\begin{array}{l}\text { tabul } \\
\text { ar }\end{array}$ & calculated & \\
\hline Male & 178.390 & 20.710 & 198 & 1,98 & 2,903 & Statistically \\
\hline
\end{tabular}




\begin{tabular}{|l|l|l|l|l|l|l|}
\hline Female & 162.860 & 34.373 & & & & significant \\
\hline
\end{tabular}

In order to verify the significant differences between the four groups in the orientation towards electronic education according to the levels of the scientific title (professor, assistant professor, instructor, assistant instructor) for the research sample, the total variance between the four groups and the value of variance within each group were calculated using the one-to-one analysis of variance (ANOVA). To determine the direction of the differences in favour of any of the four groups according to the statistical significance, the method of least significant difference (LSD) was used. It was found that the differences in favour of the first group that represent the level of the scientific title (professor) is due to the fact that there is an effect of the scientific title variable and that the professor's experience in university teaching has a role in qualitatively developing these skills.

Table (9)

A unilateral analysis of variance of the research sample scores on the orientation towards e-learning scale according to the scientific title variable.

\begin{tabular}{|l|l|l|l|l|l|l|}
\hline $\begin{array}{l}\text { Source of } \\
\text { difference }\end{array}$ & $\begin{array}{l}\text { Degree of } \\
\text { freedom }\end{array}$ & $\begin{array}{l}\text { Total of } \\
\text { squares }\end{array}$ & $\begin{array}{l}\text { Mean of } \\
\text { squares }\end{array}$ & f-value & $\begin{array}{l}\text { Significance } \\
(0.05)\end{array}$ \\
\cline { 1 - 5 } Inter-group & 3 & 7022,706 & 2340,90 & 3.949 & 5.751 & $\begin{array}{l}\text { Inter-group } \\
\text { Statistically } \\
\text { significant } \\
\text { differences }\end{array}$ \\
\hline Intra-group & 196 & 79786,01 & 407,071 & & & \\
\hline Total & 162.860 & 86808.7 & & & & \\
\hline
\end{tabular}

To validate the 10th null hypothesis, which states (there is no statistically significant difference at the significance level of $(0.05)$ in the orientation of the university professors towards electronic education according to the variable of years of experience (5 years, 10 years, 20 years. It shows that there are significant differences between the four groups in the orientation towards electronic education depending on the levels of experience
(5 years, 10 years, 15 years, 20 years) for the research sample. To confirm if the differences are in favour of any of the four groups according to the statistical method, the least significant difference (L.S.D) was used and it showed that statistical differences were for the fourth group representing the level of experience ( 5 years).

Table (10): Unilateral Analysis of variance in the orientation towards e-learning scale according to the variable of years of experience.

\begin{tabular}{|l|l|l|l|l|l|}
\hline Source of & Degree of & Total of & Mean of & f-value & Significance \\
\hline
\end{tabular}




\begin{tabular}{|c|c|c|c|c|c|c|}
\hline \multirow[t]{2}{*}{ difference } & \multirow[t]{2}{*}{ freedom } & \multirow[t]{2}{*}{ squares } & \multirow[t]{2}{*}{ squares } & & & \multirow[t]{2}{*}{$(0.05)$} \\
\hline & & & & \multirow{4}{*}{$\begin{array}{l}\text { tabular } \\
3.949\end{array}$} & calculated & \\
\hline Inter-group & 3 & $\begin{array}{l}9585.62 \\
4\end{array}$ & $\begin{array}{l}3195.20 \\
8\end{array}$ & & \multirow[t]{3}{*}{8.110} & \multirow{3}{*}{$\begin{array}{l}\text { Inter-group } \\
\text { Statistically } \\
\text { significant } \\
\text { differences }\end{array}$} \\
\hline Intra-group & 196 & $\begin{array}{l}77223.0 \\
96\end{array}$ & 393.995 & & & \\
\hline Total & 162.860 & $\begin{array}{l}86808,72 \\
0\end{array}$ & & & & \\
\hline
\end{tabular}

To verify the validity of the null hypothesis, which states that : "There is no statistically significant correlational relationship at the significance level of (0.05) between the level of university professors' ability to acquire technological skills and their tendency towards elearning.

Table (11): The relationship between technological skills and the orientation towards elearning.

\begin{tabular}{|l|l|l|l|}
\hline Variables & $\begin{array}{l}\text { Sampl } \\
\text { e }\end{array}$ & $\begin{array}{l}\text { Correlatio } \\
\mathrm{n} \\
\text { coefficien } \\
\mathrm{t}\end{array}$ & $\begin{array}{l}\text { Significanc } \\
\text { e level }\end{array}$ \\
\hline $\begin{array}{l}\text { Technologic } \\
\text { al skills }\end{array}$ & 200 & $\mathbf{0 . 3 9 5} * *$ & $\mathbf{0 . 0 1}$ \\
\cline { 1 - 2 } Direction & & & \\
\hline
\end{tabular}

It turns out that there is a relationship between technological skills and the orientation towards electronic education. The researchers attribute this relationship to the fact that technological skills are linked to the teaching performance of university professors. These skills contribute to the development of modern technology and are reflected in their orientation towards e-learning and the individuality that electronic education provides in education as well as the opportunity to make more effort, distinction and creativity so that university teaching keeps pace with technological developments.

\section{Conclusions}

1- University professors possess a higher than average level of technological skills.

2- University professors have a positive orientation towards e-learning. Knowledge is a distinctive feature of a professor related to his teaching performance.

3- The level of university professors with technological skills demonstrated a clear ability to manage electronic classes and create an active learning environment.

4- The existence of statistically significant differences between the members of the research sample in both technological skills and the orientation towards e-learning according to gender, scientific title, years of experience and scientific specialization.

5- The existence of a direct correlational relationship of statistical significance between the level that enables university professors to acquire technological skills and their orientation towards e-learning.

\subsection{Recommendations}

Based on the findings of the research, the researchers recommend the following:

1- Adopting the list of teaching skills that have been identified in the current research and making use of them by university professors in the evaluation process of college students during the practice period, to see their ability to do so. 
2- Incorporating the technological skills discussed in the current research tool in the training programs prepared for university professors.

3- Incorporating the technological skills, especially those concerned with the use of educational websites and educational programs in designing lessons within the syllabus of the teaching methods prescribed for students of the Faculties of Education and Basic Education.

4- Incorporating technological skills and educational programs within the syllabus of the computer subject prescribed for college students.

5- Educating the faculties about the importance of technological skills in improving the level of performance, as well as emphasizing their importance in the student preparation and development program.

6- Drawing the attention of university professors towards the orientation as an emotional component and strengthened it among students as a positive influence and a drive for their behaviour towards what is required to be accomplished.

7- Benefiting from the results and the tool of this research in setting quality conditions in electronic teaching at the university level.

\section{The proposals}

To complement the current research, the researchers suggest the following:

1- Applying the tool to a larger sample that includes a number of universities.

2- Conducting research aimed at uncovering the impact of building a program based on technological skills for university professors and upgrading their level.

3- Conducting a research aimed at revealing the level of university students 'ability of technological skills and its relationship to elearning.

4- Uncovering the correlation between the level of university professors' ability of technological skills and other variables such as (thinking skills, tendency, problem solving, decision-making, etc.). 5- Uncovering the correlation between the level of technological skills of university professors and its relationship to the achievement of their students.

\section{References}

[1] Abu Al-Nasr, M. (2004). Rules and stages of scientific research. Cairo: The Arab Nile Group.

[2] Al-Ajrami, S. (2012). Availability of elearning competencies among technology teachers in Gaza governorate schools in light of some variables. An-Najah University Research Journal for Human Sciences, 26(8), 1723-1760.

[3] Al-Dhamin, M. (2007). Fundamentals of Scientific Research. Amman: Dar AlMasirah.

[4] Al-Far, I. A. (2004). Computer Education at the beginning of the Twenty-first Century. Cairo: Arab Thought House.

[5] Al-Hariri, R. (2016). Teaching Methods between Tradition and Renewal (2nd ed.). Amman: Arab Thought Publishers.

[6] Al-Husban, D. (2014). The Effect of Faculty Members at Princess AAliya University College Using E-Learning Techniques in the Educational Process: a case Study. In The International Conference (pp. 335-262). Jordan.

[7] Ali, M. (2009). Scientific Education and Science Teaching (3rd ed.). Amman: Dar Al Masirah.

[8] Al-Lulu, F. (2021). The effect of a competency-based program on the professional growth of science students in the Faculties of Education in Gaza ( $\mathrm{PhD}$ thesis). Faculty of Education, Ain AlShams University.

[9] Hamza, J. (2015). Problems of using elearning in teaching historical courses from the teacher's point of view. Journal Of The College Of Basic Education For Educational And Psychological Sciences, (20), 110-123.

[10] Hassan, H. (2012). Technological competencies of faculty members of the 
College of Physical Education and the extent of their practice of it in light of some variables (Master's Dissertation). University of Baghdad.

[11] Kerlinger, F. (1979). Foundations of behavioral research. New York: Wadsworth.

[12] Khazali, Q., \& Momani, A. (2010). Teaching competencies of elementary school teachers in private schools in light of scientific qualification variables, years of experience and specialization. Damascus University Journal, 26(3), 553592.

[13] Makhzoumi, A. (1989). The behavior and attitude of students, and the attitude of students of the Faculty of Education at the University of the 9th of September in Izmir towards the Arabic language. Risalat Ul-Khaleej Al-Arabi, (31), 45.

[14] Quneibi, F. (2016). Attitudes of teachers and students towards the use of the tablet in learning and teaching in Jordanian schools. The Arab Journal Of Science, Publishing And Research, 2(16), 84-101.

[15] Othman, M., \& Al-Jundi, M. (2015). Development of Computer Courses in the Commercial and Advanced Technical High School in Light of Technological Competencies. Journal of Educational And Social Studies, 11(2), 43-85.

[16] Salem, A. (2004). Learning Technology and E-Learning. Riyadh: Al-Rasheed Library.

[17] Wahid, A. (2001). Social Psychology (1st ed.). Amman: Dar Al-Masirah. 